\title{
Piceatannol Affects Gastric Ulcers Induced by Indomethacin: Association of Antioxidant, Anti-Inflammatory, and Angiogenesis Mechanisms in Rats
}

\author{
Rasheed A. Shaik *(D) and Basma G. Eid (D) \\ Department of Pharmacology and Toxicology, Faculty of Pharmacy, King Abdulaziz University, \\ Jeddah 21589, Saudi Arabia; beid@kau.edu.sa \\ * Correspondence: rashaikh1@kau.edu.sa
}

Citation: Shaik, R.A.; Eid, B.G. Piceatannol Affects Gastric Ulcers Induced by Indomethacin: Association of Antioxidant Anti-Inflammatory, and Angiogenesis Mechanisms in Rats. Life 2022, 12, 356. https:/ /doi.org/ $10.3390 /$ life12030356

Academic Editor: Ramón Cacabelos

Received: 7 February 2022

Accepted: 23 February 2022

Published: 28 February 2022

Publisher's Note: MDPI stays neutral with regard to jurisdictional claims in published maps and institutional affiliations.

Copyright: (C) 2022 by the authors. Licensee MDPI, Basel, Switzerland. This article is an open access article distributed under the terms and conditions of the Creative Commons Attribution (CC BY) license (https:// creativecommons.org/licenses/by/ $4.0 /)$.

\begin{abstract}
One of the major aggressive factors that affect gastric injury is non-steroidal anti-inflammatory drugs (NSAIDs). Indomethacin (Indo) showed higher potentiality in gastric injury over conventional NSAIDs. Piceatannol (PIC) is a natural polyphenolic stilbene that possesses potent antioxidant and anti-inflammatory properties. The gastroprotective properties of PIC have been overlooked previously. Hence, we aim to study gastric injury induced by Indo and the protective action manifested by PIC, as well as to elucidate the likely underlying mechanisms of action in a rat model. The rats have been treated with vehicle, Indo alone, combined treatment with Indo, and PIC at $(5 \mathrm{mg} / \mathrm{kg}$ or $10 \mathrm{mg} / \mathrm{kg}$ ), respectively. The rats were also treated with Indo and omeprazole. In our study, we found that PIC at both 5 and $10 \mathrm{mg} / \mathrm{kg}$ doses was effective by averting the rise in ulcer and lesion indices, acid production, and histological variations persuaded by Indo. Mechanistically, PIC significantly reduced lipid peroxidation product (MDA), increased the GSH content, and enhanced SOD and CAT activity. In addition, PIC exhibits a distinct reduction in the levels of inflammatory parameters (Cox-2, IL-6, TNF- $\alpha$, and NFKB). Contrastingly, PIC augmented both mucin and PGE2 content. Moreover, PIC fostered angiogenesis by increasing the expression of proangiogenic factors (VEGF, bFGF, and PDGF). Overall, the above results suggest PIC exhibits a potential protective effect against Indo-induced gastric ulcers by the antioxidant, anti-inflammatory, and angiogenic mechanisms.
\end{abstract}

Keywords: indomethacin; piceatannol; gastric ulcers

\section{Introduction}

Major gastrointestinal diseases like gastric ulcers occur because of misproportioning between aggressive and protective factors in the stomach [1]. Belligerent aspects of the disease may involve nonsteroidal anti-inflammatory drugs (NSAIDs), smoking, mental stress, alcohol, and H. pylori infection. Protective factors may include growth factors, cell renewal, mucosal blood flow, nitric oxide (NO), prostaglandins, etc. [2]. NSAIDs are the most widely used analgesic and anti-inflammatory drugs [3]. NSAIDs are considered not only to induce gastric damage, but via various mechanisms, they delay the healing of ulcers [4]. Previously, indomethacin (Indo) has been shown to have a greater potentiality to cause gastric damage than conventional NSAIDs [5]. Previous Indo-induced ulcer studies showed that it inhibits the synthesis of prostaglandin-E2 (PGE2) or angiogenesis, facilitates the formation of free radicals, induces cyclooxygenase -2 (COX-2) expression, and induces cytokines responsible for pro-inflammatory actions [6,7]. Additionally, down-regulation of pro-angiogenic factors, like vascular endothelial growth factor (VEGF), platelet-derived growth factor (PDGF), and basic fibroblast growth factor (bFGF) by NSAIDs, delays healing of ulcers $[8,9]$.

Piceatannol (PIC) is a natural polyphenolic stilbene found in peanuts, berries, sugar cane, white tea, grapes, and more. [10-12]. It has been reported that PIC has the potential for the management of chronic diseases [13]. Previous studies showed that PIC causes 
scavenging of free radicals and exerts potent antioxidant properties [14]. Furthermore, it can upregulate antioxidant-mediated defense mechanisms [15]. PIC also showed potent anti-inflammatory actions in both in vivo and in vitro studies [16]. The key mechanism behind its anti-inflammatory actions is the inhibition of COX-2, NF- $\mathrm{B}, \mathrm{PGE} 2$, and cytokines, such as TNF- $\alpha$ (Tumor Necrosis Factor- $\alpha$ ), IL-6 (interleukin-6), interleukin-1 $\beta$ (IL1 $\beta)$, and NO $[15,17,18]$. All these properties could prove to be beneficial in preventing the development of gastric ulcers. The gastro-protective properties of PIC were previously overlooked. Hence, we aim to conduct our present study to explore Piceatannol's mediated protective actions against Indo-induced gastric injury and elucidate the possible underlying mechanism(s) of action. We propose that PIC with its antioxidant and anti-inflammatory properties would protect against Indo-induced gastric ulceration in rats. This study could open new therapeutic potentials for natural products in the treatment of inflammatory diseases including peptic ulcers.

\section{Materials and Methods}

\subsection{Use of Chemicals/Drugs}

PIC, Indo, omeprazole, and carboxymethyl cellulose sodium (CMC-Na) were bought from (Sigma, St. Louis, MO, USA). Formalin, phosphate buffer, and all other necessary commercially available chemicals were selected based on the highest purity grade.

\subsection{Study of Animals}

In this study, adult male Wistar rats that weighed in the range of 200 to $220 \mathrm{~g}$ (10-12 weeks) were procured (source: Faculty of Pharmacy, KAU, Jeddah, KSA). The rats were housed in the animal house at controlled room temperature with relative humidity (50-55\%), under a twelve-hour cycle (light and dark), at the Pharmacy faculty, KAU, department of pharmacology. The rats were allowed to acclimatize for one week to their environment and fed standard pelleted nutrients with spontaneous feeding of water. The whole experimental protocols have been carried out under the guidelines of the National Institute of Health (Animal care; NIH Pub no-8023; Revision no- 1978). Approval for this research has been obtained by the formed committee of research ethics of Pharmacy faculty, King Abdulaziz University (ref no- PH133-41).

\subsection{Design of Experiments}

Thirty rats were randomly divided into five groups $(n=6)$.

Group 1 (control): this group received the vehicle (CMC-Na 0.5\% w/v, 10mL/ kg).

Group 2 (Indo): this group received only Indo $(50 \mathrm{mg} / \mathrm{kg})$ in a single shot, oral administration.

Group 3 (Indo + PIC $5 \mathrm{mg} / \mathrm{kg}$ ), and group 4 (Indo + PIC $10 \mathrm{mg} / \mathrm{kg}$ ): in these groups, PIC was administered orally, $5 \mathrm{mg} / \mathrm{kg}$ and $10 \mathrm{mg} / \mathrm{kg}$, for seven days. On the seventh day, rats were given Indo $50 \mathrm{mg} / \mathrm{kg}$ orally followed $1 \mathrm{hr}$ later by the last dose of PIC.

Group 5 (Indo + Omeprazole): an oral dose of omeprazole (30 mg/ kg) was given for seven days. On the seventh day, rats were given Indo $50 \mathrm{mg} / \mathrm{kg}$ orally followed $1 \mathrm{~h} \mathrm{later}$ by the last dose of omeprazole. The antioxidant and anti-inflammatory properties of PIC have been tested at several dose levels in previous studies [19]. After four hours of Indo intoxication, rats in treatment groups were dissected.

\subsection{Gastric Ulcer Induction}

According to previous reports, Indo caused gastric ulceration [20]. The rats were deprived of the food supply with the liberty of water supply for $24 \mathrm{~h}$ on the sixth day. On the seventh day, Indo $50 \mathrm{mg} / \mathrm{kg}$ suspended in $0.5 \%$ CMC-Na was intragastrically administrated to all groups except the control group. 


\subsection{Measurement of Gastric Juice Volume and $\mathrm{pH}$}

After $4 \mathrm{~h}$ of Indo administration, ketamine $(60 \mathrm{mg} / \mathrm{kg})$ and xylazine $(10 \mathrm{mg} / \mathrm{kg})$ anesthesia was applied, and the abdomen was dissected. Thereafter, gastric pylorus was ligated followed by removal of the stomach portion and dissected via greater curvature. The stomach contents were immediately collected and transferred into a centrifugal tube followed by centrifugation for $5 \mathrm{~min}$ at $2500 \times \mathrm{g}$ for eliminating debris before measuring the amounts of supernatants. A digital $\mathrm{pH}$ meter was used to measure the $\mathrm{pH}$ of the gastric juice (PHscan 40, Pocket PH tester, BANTE, China).

\subsection{Morphological and Histological Examination}

The rats' stomachs were cut and rinsed with normal saline $(0.9 \% \mathrm{NaCl})$. Digital photography was used for taking images. Through microscopy, the glandular mucus layers of the stomachs were then inspected to look for hemorrhagic lesions. Each lesion's length was measured in millimeters ( $\mathrm{mm}$ ). The ulcer index was calculated using the equation below:

$$
\text { Ulcer index }=10 \div \mathrm{x}
$$

$\mathrm{x}=$ the total ulcerated / mucosal area [21].

The samples (tissues) were fixed in formalin to produce paraffin blocks before being sliced as $4 \mu \mathrm{m}$ thick sections with a sliding microtome. Staining was done by eosin and hematoxylin and inspected under the light microscope (Nikon, Eclipse) for routine histological examination [22]. A histopathologist evaluated the pathological alterations and other scoring according to a previous study [23].

\subsection{Mucin Protein Assessment}

By using a Rat MUC1 ELISA kit (cat $\neq$ NBP2-74991, Novus Biologicals, CO, USA), mucin protein was assessed based on the sandwich technique. Stomach tissues were chopped into fine particles and, to remove excess blood, thoroughly washed in ice-cold phosphate-buffered saline (PBS). Tissue pieces were taken for measuring their weight and homogenization was performed in PBS with glass homogenizer in ice as $w / v$ of tissue weight $(\mathrm{g})$ : PBS $(\mathrm{ml})=1: 9$. The homogenates were centrifuged at $5000 \times \mathrm{g}$ for $5 \mathrm{~min}$ for obtaining supernatant. Each well received $100 \mu \mathrm{L}$ of standard or sample and was incubated for $90 \mathrm{~min} / 37^{\circ} \mathrm{C}$. The supernatant was discarded and $100 \mu \mathrm{L}$ of detection antibody was incubated for $1 \mathrm{~h} / 37^{\circ} \mathrm{C}$ before being aspirated and washed as thrice. After that, $100 \mu \mathrm{L}$ of HRP conjugate was added and incubated for $30 \mathrm{~min} / 37^{\circ} \mathrm{C}$; aspirating followed by washing five times. A total of $90 \mu \mathrm{L}$ of substrate reagent was incubated for $15 \mathrm{~min} / 37^{\circ} \mathrm{C}$ followed by adding a $50 \mu \mathrm{L}$ stop solution and the optical density (OD) at $450 \mathrm{~nm}$ was measured immediately.

\subsection{Assessment of Oxidative Stress Markers}

MDA was determined using a biochemical kit (Cat. no MD 2529, Bio diagnostic, Giza, Egypt). Thiobarbituric acid (TBA) reacted with malondialdehyde (MDA) for half an hour in an acidic medium at $95^{\circ} \mathrm{C}$ to form thiobarbituric acid reactive product. The absorbance of the pink product that resulted was measured at $534 \mathrm{~nm}$. The product (thiobarbituric acid reactive product) was formed after $30 \mathrm{~min}$ of TBA (thiobarbituric acid) reaction with MDA (malondialdehyde) in an acidic medium at $95^{\circ} \mathrm{C}$ [23]. Glutathione (GSH) was measured by using the biochemical kit (Cat. No K264, Biovision, Milpitas, CA, USA). SOD enzymatic activity was measured by a colorimetric method using a biochemical kit (Cat. No. SD 2521, Biodiagnostic, Giza, Egypt) [24] and CAT activity was measured biochemically (Cat. no CA 25 17, Bio diagnostic, Giza, Egypt) [25].

\subsection{Prostaglandin E2 (PGE2) Assessment}

PGE2 activity evaluation in gastric tissue homogenates was carried out by Rat Prostaglandin E2 (PGE2) ELISA Kit (cat \# CSB-E07967r, Cusabio, Houston, TX, USA), based on competitive inhibition enzyme immunoassay technique. 


\subsection{Immunohistochemical Assessment of Cox-2, IL-6, TNF- $\alpha, N F-\kappa \beta$, and VEGFA}

For immunohistochemical studies, sample sections were incubated with primary antibodies: COX-2 (cat\# ab179800 Abcam ${ }^{\circledR}$, Cambridge, UK), IL-6 (Cat\# ab9324, Abcam ${ }^{\circledR}$, Cambridge, UK), TNF $\alpha$ (Cat. No.: ab220210, Abcam $^{\circledR}$, Cambridge, UK), NFkB (Cat\# ab194726 Abcam $^{\circledR}$, Cambridge, UK), and VEGFA (Cat\# ab231260 Abcam ${ }^{\circledR}$, Cambridge, UK) for $12 \mathrm{~h} / 4^{\circ} \mathrm{C}$. After a TBS rinse, samples were incubated in anti-mouse or anti-rabbit biotinylated secondary antibody, depending on the primary antibody reactivity. (Cell \& Tissue Staining Kit, Cat. No.: CTS002 \& CTS005, R\&D systems, Minneapolis, MN, USA). Images had quantified by image analysis software (Image J, 1.46a, NIH, Bethesda, MD, USA) with a minimum of three sections per rat. It is noteworthy to report that only nuclear reactivity was considered when assessing the expression of NFkB.

\subsection{Quantitative Reverse Transcriptase PCR (qRT-PCR)}

The GeneJET Kit was used to harvest total RNA (Thermo Fisher Scientific Inc. Germany, Cat no. K0732). Then one step qRT-PCR was performed by using SensiFAST ${ }^{\mathrm{TM}}$ SYBR $^{\circledR}$ Hi-ROX One-Step Kit (Cat no. PI-50217V). The primers that have been used as per sequences are mentioned in Table 1. After qRT-PCR amplification, the mRNA fold change was calculated by normalizing the gene of interest with the housekeeping gene and

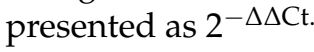

Table 1. Primer sequence of target genes.

\begin{tabular}{|c|c|}
\hline & Primer $\left(5^{\prime}\right.$ to $\left.3^{\prime}\right)$ \\
\hline \multirow{2}{*}{ PDGF } & F: ATTGGCAATGAGCGGTTCCGC \\
\hline & R: CTCCTGCTTGCTGATCCACATC \\
\hline \multirow{2}{*}{$B F G F$} & F: TGGCATTCTCAGGTTCTGGCCATT \\
\hline & R: TGGCATTCTCAGGTTCTGGCCATT \\
\hline \multirow{2}{*}{$\beta$-Actin } & F: TCCGTCGCCGGTCCACACCC \\
\hline & R: TCACCAACTGGGACGATATG \\
\hline
\end{tabular}

\subsection{Statistical Analysis}

All data are presented as means \pm SD. Ulcer index data were analyzed by KruskalWallis test followed by Dunn multiple comparison tests. The other data were analyzed by one-way analysis of variance (ANOVA), followed by Tukey's multiple comparison test to detect significant differences. A value of $p<0.05$ was considered statistically significant. GraphPad Prism software version 8 (GraphPad Software, Inc., La Jolla, CA, USA) was used for statistical analysis.

\section{Results}

\subsection{Effects of PIC on Gastric Juice Volume and $p H$}

Gastric juice volume and $\mathrm{pH}$ in the control group were $1.10 \mathrm{~mL}$ and 3.83 units. The Indo group showed (Figure 1A) a significant rise in gastric juice volume $(2.74 \mathrm{~mL})$ and a substantial (Figure 1B) reduction in gastric juice $\mathrm{pH}$ (1.9 units). PIC at both 5 and $10 \mathrm{mg} / \mathrm{kg}$ doses considerably reduced gastric juice quantity $(1.88 \mathrm{~mL} \& 1.2 \mathrm{~mL})$ and elevated gastric juice $\mathrm{pH}$ (2.37 \& 3.47 units) (Figure 1A,B). Omeprazole significantly reduced gastric juice volume $(0.95 \mathrm{~mL})$ and elevated gastric juice $\mathrm{pH}$ (4.35 units) markedly (Figure 1A,B). Indo + PIC $10 \mathrm{mg} / \mathrm{kg}$ and Indo + Omeprazole showed an almost similar significant effect (Figure 1A,B). 


\section{A}

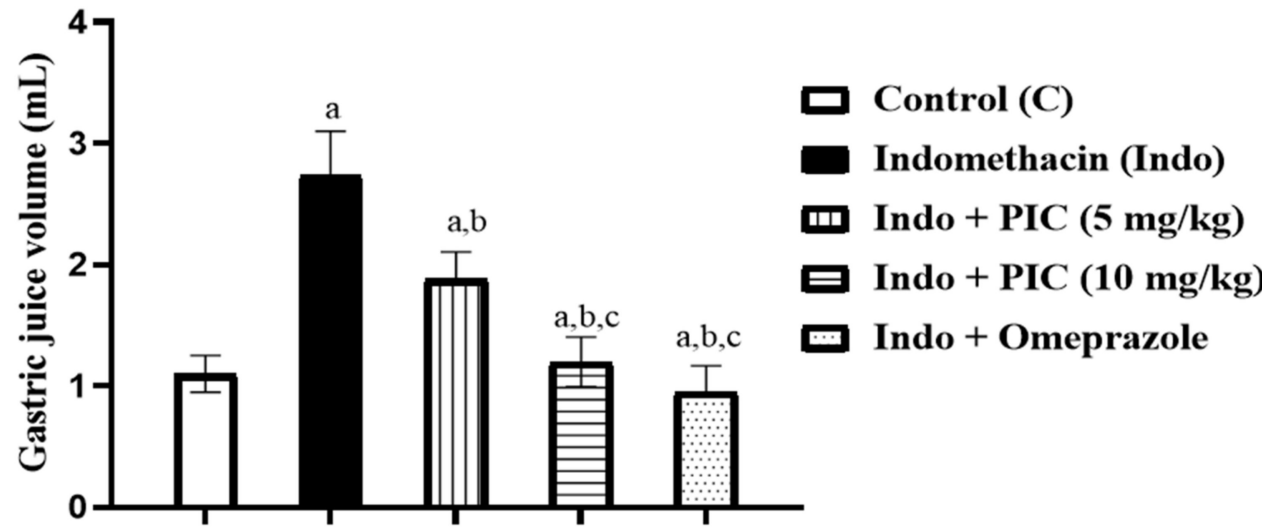

B

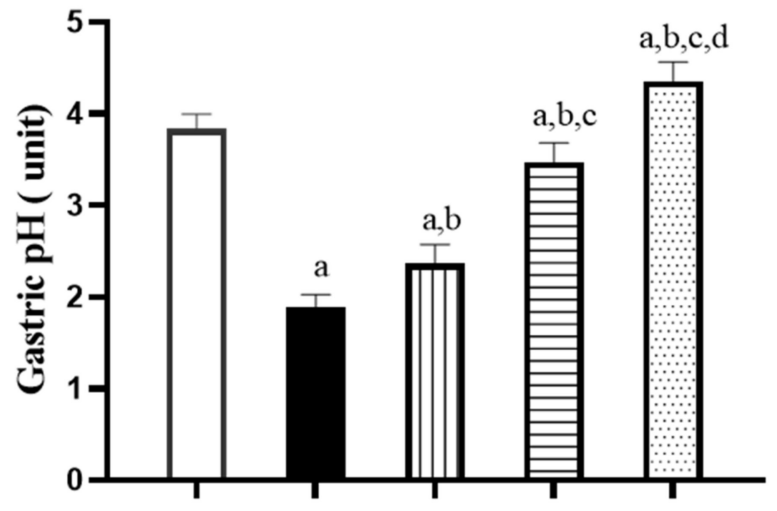

$\begin{array}{ll}\square & \text { Control (C) } \\ \text { Indomethacin (Indo) } \\ \square \text { Indo + PIC (5 mg/kg) } \\ \square \text { Indo + PIC (10 mg/kg) } \\ \square \text { Indo + Omeprazole }\end{array}$

Figure 1. Effects of PIC on gastric juice volume and $\mathrm{pH}$. (A) Gastric juice volume for different groups. (B) Gastric $\mathrm{pH}$ for different groups. Data are presented as Mean $\pm \mathrm{SD}(\mathrm{n}=6)$. a: Significantly disparate with control $(p<0.05)$; b: significantly disparate with Indo $(p<0.05)$; : significantly disparate with Indo + PIC $(5 \mathrm{mg} / \mathrm{kg})(p<0.05)$; and d: significantly disparate with Indo + PIC $(10 \mathrm{mg} / \mathrm{kg})(p<0.05)$.

\subsection{Effect of PIC Pretreatment on Stomach Morphology and Histopathology}

The mucous lining in the stomach of the control group was normal and null injury was noted (Figure 2A). Nevertheless, the Indo group exhibited bloody streaks injuries ranging from $0.5-5 \mathrm{~mm}$ in size (Figure $2 \mathrm{~B}$ ), as measured by the dramatic rise in ulcer index (Figure 2F). Indo+ PIC ( $5 \mathrm{mg} / \mathrm{kg}$ ) exhibited bloody streaks, although to a smaller extent as compared with the Indo group (Figure 2C). Rats given Indo+ PIC (10 mg/kg) showed superficial blood vessel blockage suggesting minor injuries, with a marked decline in ulcer index than the Indo group (Figure 2D). Omeprazole treatment safeguarded the layer of gastric mucosa, with no marked variation in ulcer index compared to control (Figure 2E,F).

As shown in Figure 3, in contrast, to the control group, serious histopathological alterations were detected in the Indo group. Multifocal ulcerative areas were detected in the glandular mucosa which was characterized by desquamation of the epithelial lining admixed with hemorrhages and accumulation of necrotic tissue and hemosiderin pigment. Numerous sections showed excessive inflammatory cells infiltration in the mucosa and submucosal layers. The submucosa layer revealed dispersion of the connective tissue with abundant edema, congested blood vessels, and inflammatory cells infiltration. The examination of Indo+ PIC ( $5 \mathrm{mg} / \mathrm{kg}$ ) revealed a few changes characterized by mild epithelial sloughing with numerous inflammatory cells infiltration in the mucosa and submucosal layer. Microscopic examination of Indo + PIC $(10 \mathrm{mg} / \mathrm{kg})$ showed the mostly normal 
histological structure of glandular mucosa and submucosa with minor injuries in several examined sections. A normal glandular stomach was observed in omeprazole pretreated rats as well. The statistical evaluation of total histopathological alterations exhibited a significant rise in the Indo group in comparison to control or treated groups. The absence of significant difference was observed between Indo + PIC $10 \mathrm{mg} / \mathrm{kg}$ and Indo + Omeprazole (Figure 3D,E).
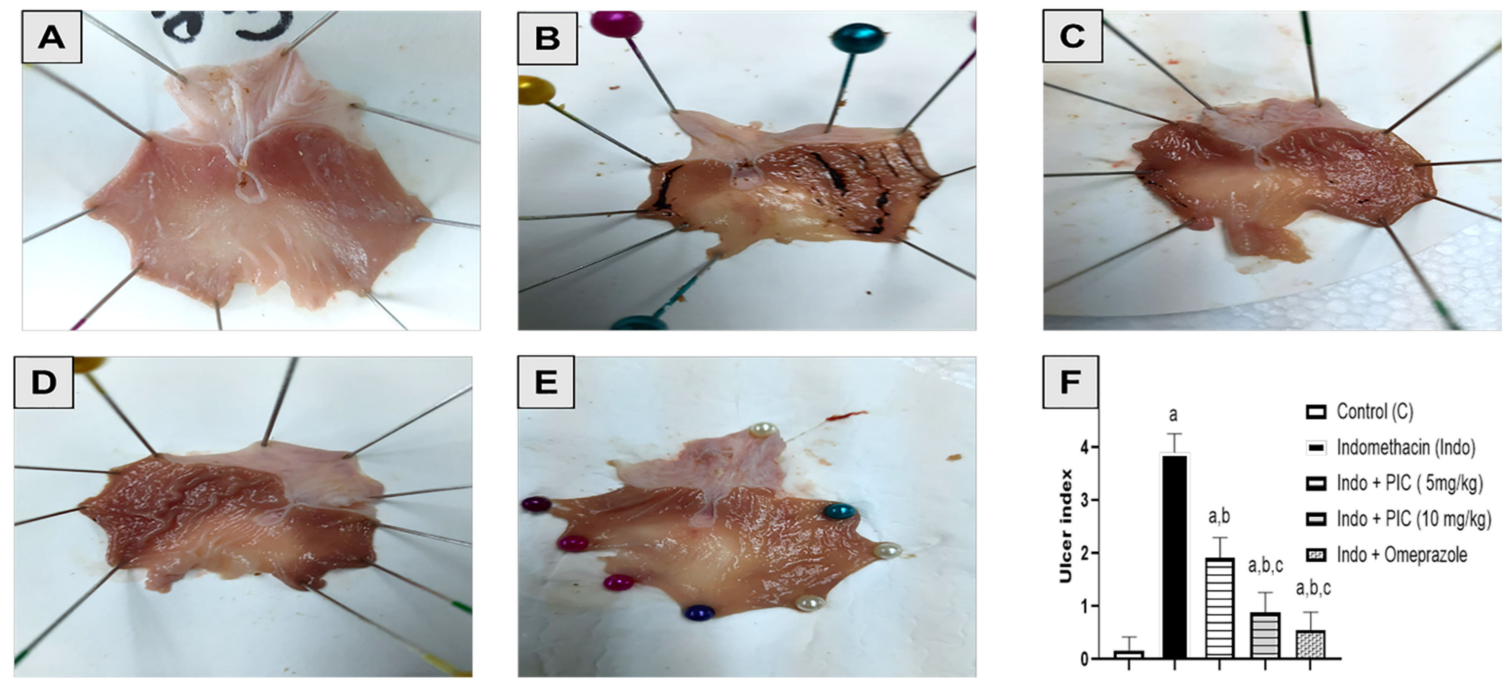

Figure 2. Macroscopic photographs of rat's Stomachs. (A) The Control group showed gastric mucosa with no lesion or redness. (B) Rats with treated Indo had a severely hemorrhagic ulcerated mucous surface. (C) Indo + PIC (5 mg/ kg) showing superficial injuries. (D) Indo + PIC (10 mg/kg) showing minor injuries with normal mucosa. (E) Indo + Omeprazole effectively normalizes the damaged mucosal layer and shows no redness or damage. $(F)$ Ulcer index. The data are presented as mean \pm SD. a: Significantly disparate with control $(p<0.05)$; b: significantly disparate with Indo $(p<0.05)$ and $\mathrm{c}$ : significantly disparate with Indo + PIC $(5 \mathrm{mg} / \mathrm{kg})(p<0.05)$.
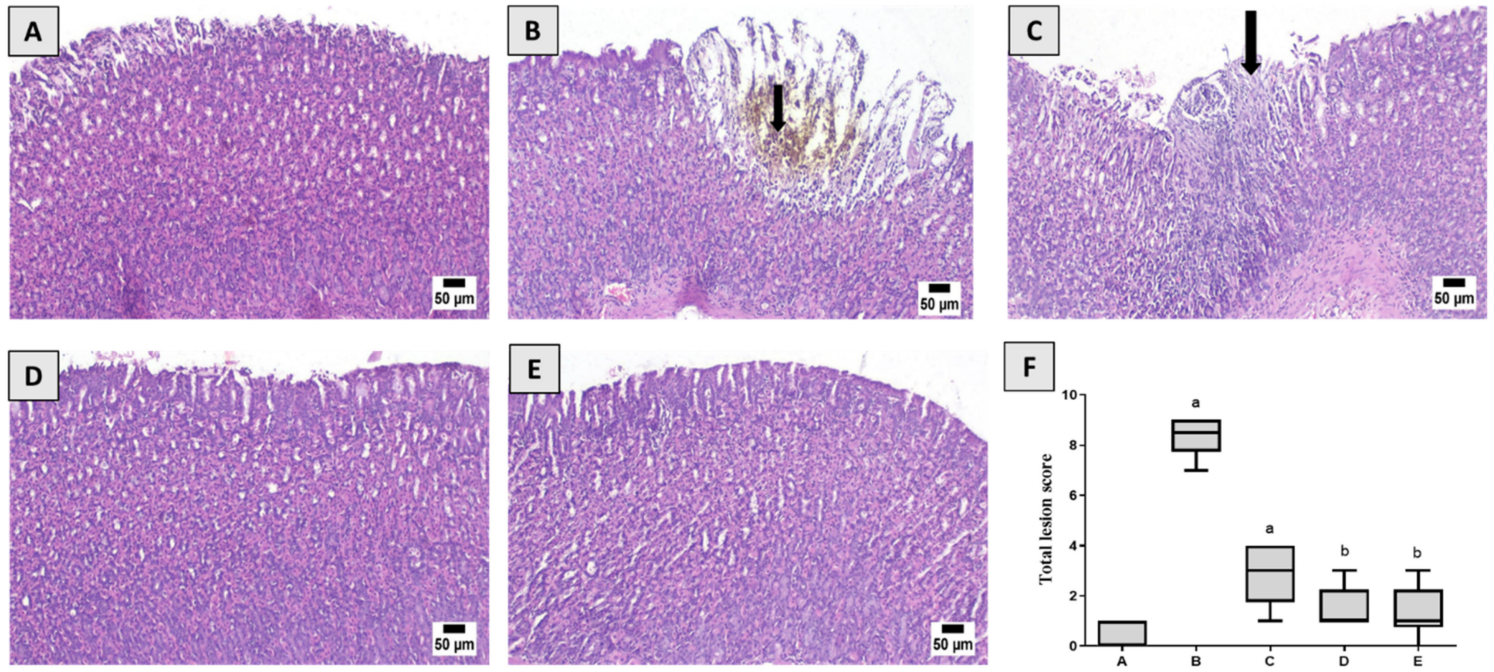

Figure 3. Histological examination. (A) Stomach from control group showing normal gastric mucosa. (B) Stomach from the Indo-treated group showing ulcerative mucosal surface associated with deposition of hemosiderin pigment (arrow). (C) Stomach from Indo + PIC (5 mg/kg) showing focal necrosis of mucosal surface (arrow). (D) Stomach from Indo + PIC (10 mg/kg) showed apparently normal mucosa. (E) Stomach from Indo + omeprazole showed normal stomach mucosa. (F) Total lesion score. The data are presented as mean \pm SD. a: Significantly disparate with control $(p<0.05)$; b: significantly disparate with Indo $(p<0.05)$. 


\subsection{PIC Affects the Mucin Content}

Our results indicated that the Indo group markedly decreased mucin level by $63.66 \%$ compared to the control, whereas the decline was significantly reversed by PIC ( 5 \& $10 \mathrm{mg} / \mathrm{kg}$ ) and omeprazole treatments by 1.77-, 1.83-, and 2.26-fold, respectively (Figure 4).

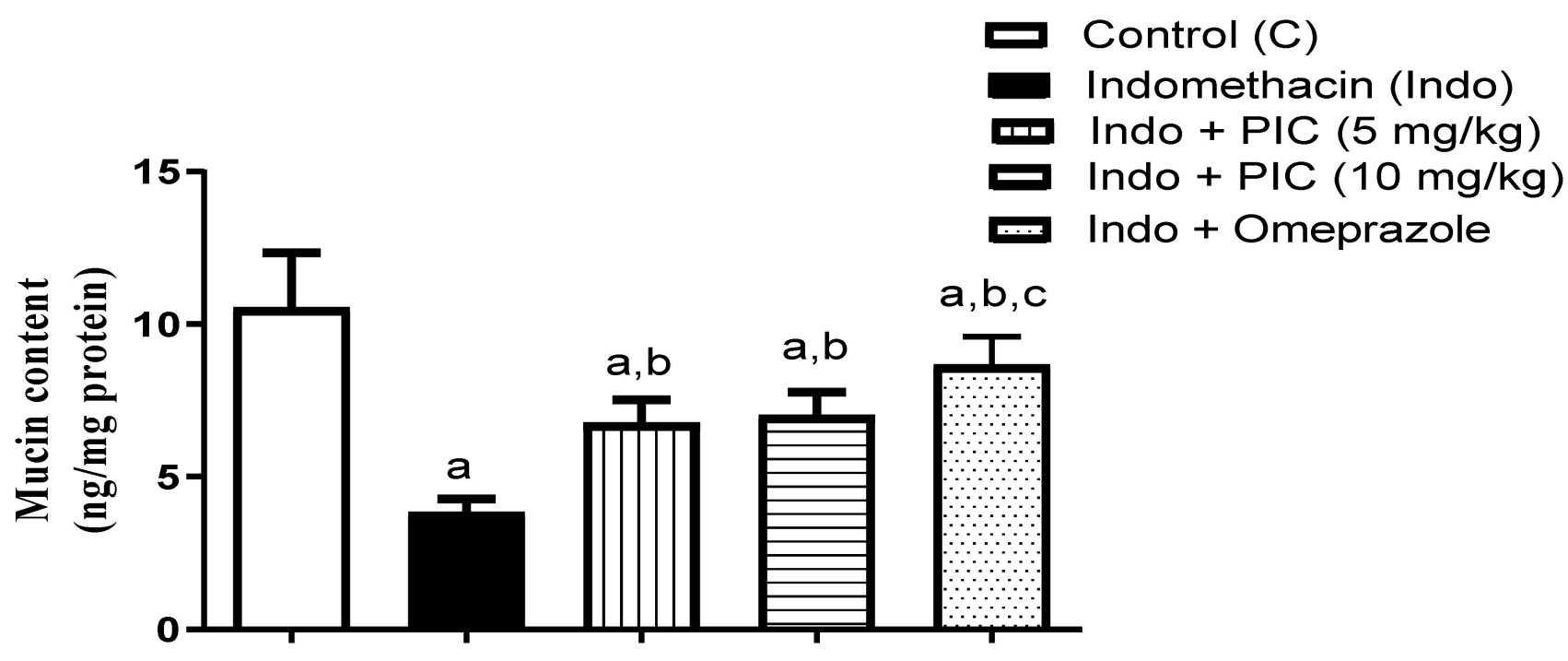

Figure 4. The mucin level in gastric tissue after PIC treatment with Indo. Data are presented as Mean $\pm \mathrm{SD}(\mathrm{n}=6)$. a: Significantly disparate with control $(p<0.05)$. b: Significantly disparate with Indo $(p<0.05)$; c: Significantly disparate with Indo + PIC $(5 \mathrm{mg} / \mathrm{kg})(p<0.05)$.

\subsection{PIC Affects the Oxidative Stress Denoting Markers}

PIC mediated antioxidant actions had been evaluated by measuring MDA level, GSH content, and SOD and CAT activity in gastric homogenate. As revealed in Table 2, Indo caused MDA accumulation, GSH depletion, and CAT and SOD exhaustion by $470.83 \%$, $70.45 \%, 55.31 \%$, and $45.45 \%$, respectively, compared to control group. PIC (5 or $10 \mathrm{mg} / \mathrm{kg}$ ) and omeprazole treatment significantly reduced the MDA level by $31.38 \%, 43.55 \%$, and $58.64 \%$, with respect to the Indo group (Table 2). A substantial rise in gastric GSH content was observed in PIC ( 5 or $10 \mathrm{mg} / \mathrm{kg}$ ) and omeprazole groups by $46.15 \%, 61.53 \%$, and $76.92 \%$, respectively. Rats pretreated with PIC (5\& $10 \mathrm{mg} / \mathrm{kg}$ ) and omeprazole showed a significant increase in SOD activity by $39 \%, 65.75 \%$, and $88.17 \%$, respectively. Moreover, a marked rise in CAT activity has been reported in PIC ( 5 or $10 \mathrm{mg} / \mathrm{kg})$ and omeprazole groups by $41.66 \%, 60.41 \%$, and $47.91 \%$, respectively, when compared with the ulcer control group (Table 2).

Table 2. PIC effects on oxidative stress biomarkers.

\begin{tabular}{ccccc}
\hline & $\begin{array}{c}\text { MDA } \\
\text { (nmol/mg } \\
\text { Protein) }\end{array}$ & $\begin{array}{c}\text { GSH } \\
\text { Prg/mg } \\
\text { Protein) }\end{array}$ & $\begin{array}{c}\text { SOD } \\
\text { (U/mg Protein) }\end{array}$ & $\begin{array}{c}\text { CAT } \\
\text { (U/mg Protein) }\end{array}$ \\
\hline Control (C) & $0.72 \pm 0.09$ & $0.44 \pm 0.05$ & $39.92 \pm 4.21$ & $0.88 \pm 0.10$ \\
\hline Indomethacin (Indo) & $4.11^{\mathrm{a}} \pm 0.45$ & $0.13^{\mathrm{a}} \pm 0.02$ & $17.84^{\mathrm{a}} \pm 2.10$ & $0.48^{\mathrm{a}} \pm 0.06$ \\
\hline Indo + PIC $(5 \mathrm{mg} / \mathrm{kg})$ & $2.82^{\mathrm{a}, \mathrm{b}} \pm 0.31$ & $0.19^{\mathrm{a}, \mathrm{b}} \pm 0.02$ & $24.80^{\mathrm{a}, \mathrm{b}} \pm 2.86$ & $0.68^{\mathrm{a}, \mathrm{b}} \pm 0.08$ \\
\hline Indo + PIC $(10 \mathrm{mg} / \mathrm{kg})$ & $2.32^{\mathrm{a}, \mathrm{b}, \mathrm{c}} \pm 0.28$ & $0.21^{\mathrm{a}, \mathrm{b}} \pm 0.02$ & $29.57^{\mathrm{a}, \mathrm{b}} \pm 3.31$ & $0.77^{\mathrm{b}} \pm 0.09$ \\
\hline Indo + Omeprazole & $1.70^{\mathrm{a}, \mathrm{b}, \mathrm{c}, \mathrm{d}}+0.19$ & $0.23^{\mathrm{a}, \mathrm{b}} \pm 0.03$ & $33.57^{\mathrm{a}, \mathrm{b}, \mathrm{c}} \pm 3.94$ & $0.71^{\mathrm{a}, \mathrm{b}} \pm 0.09$ \\
\hline
\end{tabular}

Data are presented as Mean \pm SD $(n=6) .{ }^{a}$ : Significantly disparate with control $(p<0.05) .{ }^{b}$ : Significantly disparate with Indo $(p<0.05) .{ }^{c}$ : Significantly disparate with Indo + PIC $(5 \mathrm{mg} / \mathrm{kg})(p<0.05) .{ }^{\mathrm{d}}$ : Significantly disparate with Indo + PIC $(10 \mathrm{mg} / \mathrm{kg})(p<0.05)$ 


\subsection{The Level of Gastric PGE2 Content}

Administration of Indo showed a significant decrease in the gastroprotective PGE2 level; $65.83 \%$ in comparison with the control. However, pretreatment with PIC (5mg and $10 \mathrm{mg} / \mathrm{kg}$ ) or omeprazole considerably augmented the PGE2 level by $77.58 \%, 128.86 \%$, and $122.41 \%$, compared to the Indo group, respectively. (Figure 5).

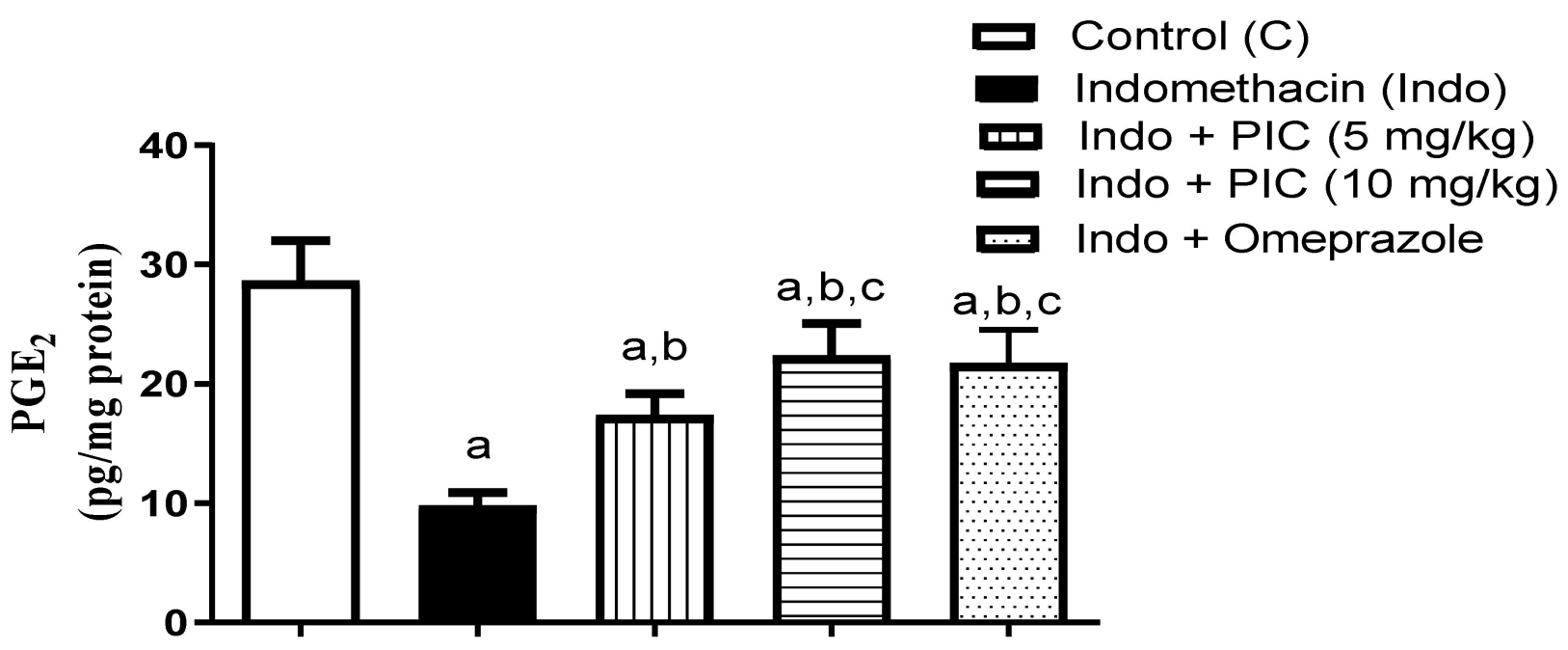

Figure 5. The level of gastric PGE2 content after PIC treatment with Indo. Data are presented as Mean \pm SD $(n=6)$. a: Significantly disparate with control $(p<0.05)$. b: Significantly disparate with Indo $(p<0.05)$; c: Significantly disparate with Indo + PIC $(5 \mathrm{mg} / \mathrm{kg})(p<0.05)$.

\subsection{Immunohistochemical Assessment of Cox-2, IL-6, TNF- $\alpha, N F-\kappa \beta$, and VEGFA}

Administration of Indo significantly increased the expression of Cox-2, IL-6, TNF- $\alpha$, and NF- $\kappa \beta$ by $147.62 \%, 152.63 \%, 114.63 \%$, and $127 \%$, respectively, compared to the control group. Pretreatment with PIC $5 \mathrm{mg} / \mathrm{kg}$ resulted in respective decreases in their expression of $36.53 \%, 23 \%, 20.45 \%$, and $26.19 \%$, compared to the Indo group. The rats treated with PIC $10 \mathrm{mg} / \mathrm{kg}$ and Indo exhibited decreases in their expression of $53.84 \% 41.7 \%, 41 \%$, and $43 \%$, respectively. In addition, pretreatment with omeprazole showed an increased expression of Cox-2 like Indo. Furthermore, omeprazole-induced decreased expression of IL- 6 , TNF- $\alpha$, and NF- $\kappa \beta$ by $58 \%, 48 \%$, and $47.7 \%$, respectively, compared to the Indo group. However, VEGFA expression was markedly reduced by $43 \%$ after Indo treatment compared to the control group. The PIC ( 5 or $10 \mathrm{mg} / \mathrm{kg}$ ) and omeprazole $30 \mathrm{mg} / \mathrm{kg}$ groups showed significant increases in VEGFA expression, 55\%, 70\%, and 60\%, respectively, in comparison with the Indo group. The immunohistochemical findings have been presented in Figure 6A,B.

\subsection{Effect of PIC on mRNA Expression Levels of bFGF and PDGF Marker Genes}

Rats treated with Indo showed a significant decrease in the bFGF mRNA expression by $64.77 \%$ compared to the control (Figure $7 \mathrm{~A}$ ). PIC (5 or $10 \mathrm{mg} / \mathrm{kg}$ ) prevented the downregulation by $38.23 \%$ and $89.48 \%$, respectively. In addition, omeprazole also prevented the decrease in their expression by $167.6 \%$ compared to the Indo group. Moreover, Indotreated rats showed significant downregulation in PDGF expression by $60.96 \%$ compared to the control values (Figure 7B). Pretreatment with PIC (5 or $10 \mathrm{mg} / \mathrm{kg}$ ) and omeprazole $30 \mathrm{mg} / \mathrm{kg}$ prevented the downregulation by $9.23 \%, 46.92 \%$, and $104.6 \%$, respectively (Figure 7B). 


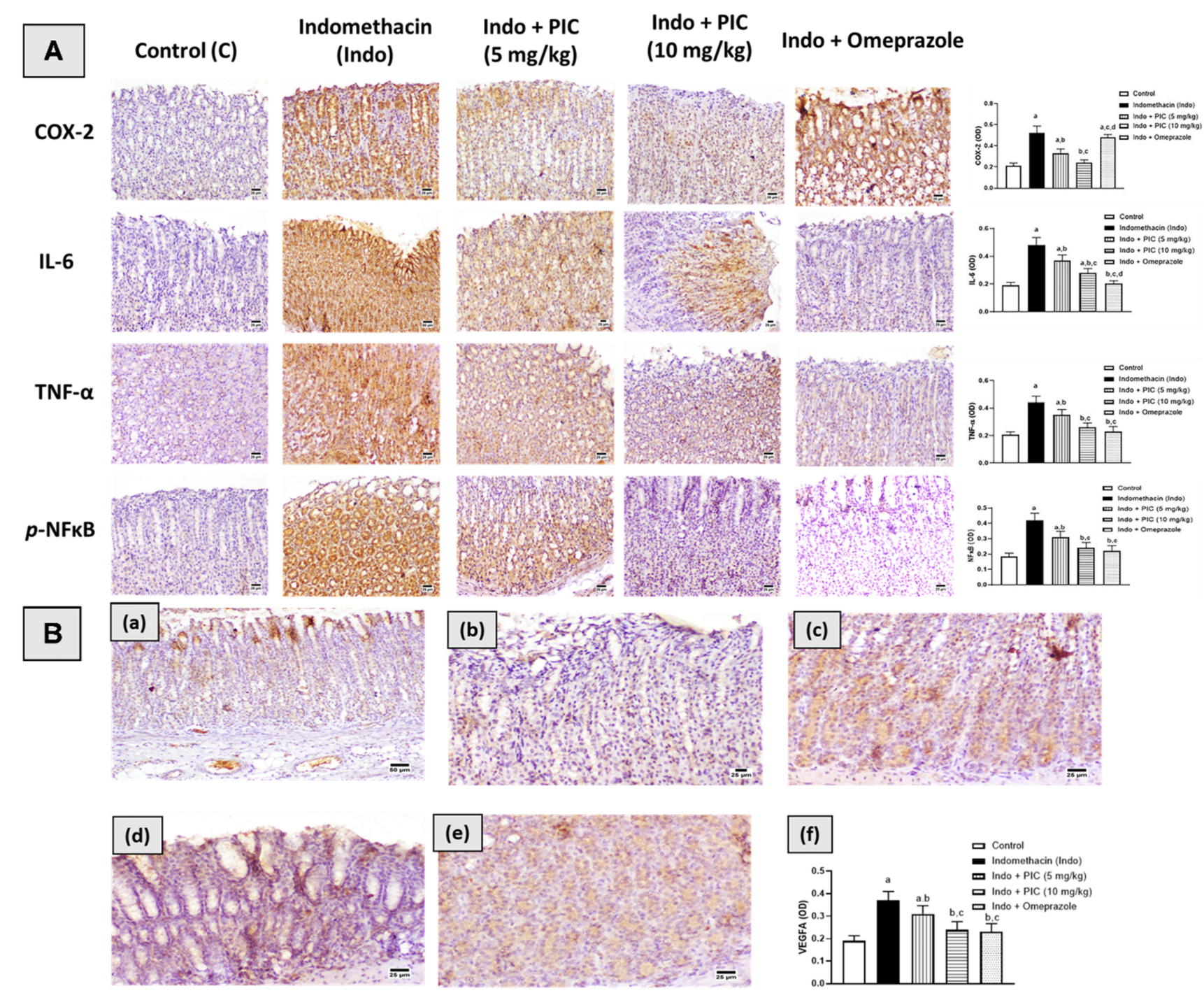

Figure 6. Immunohistochemistry examination of Inflammatory markers and proangiogenic factor. (A). Immunohistochemistry examination of Cox-2, IL-6, TNF- $\alpha$, and p-NF- $\mathrm{k} \beta$ expression in stomach sections. (B): Immunohistology photomicrographs of stomach sections demonstrating the effect of PCI on Indo-induced alteration in VEGFA. (a) The Control group shows an intense expression of VEGFA. (b) The Indo-treated group shows a decreased expression of VEGFA. (c) Indo + PIC $(5 \mathrm{mg} / \mathrm{kg})$ group shows a moderate expression of VEGFA. (d) Indo + PIC $(10 \mathrm{mg} / \mathrm{kg})$ group shows an intense expression of VEGFA. (e). Indo + Omeprazole group shows increase expression of VEGFA. (f) Quantitative image analysis for VEGF immunohistochemical staining, expressed as optical density (OD). The data are presented as mean \pm SD. a: Significantly disparate with control $(p<0.05)$; b: significantly disparate with Indo $(p<0.05)$; c: significantly disparate with Indo + PIC $(5 \mathrm{mg} / \mathrm{kg})$ $(p<0.05)$; and d: significantly disparate with Indo + PIC $(10 \mathrm{mg} / \mathrm{kg})(p<0.05)$. 


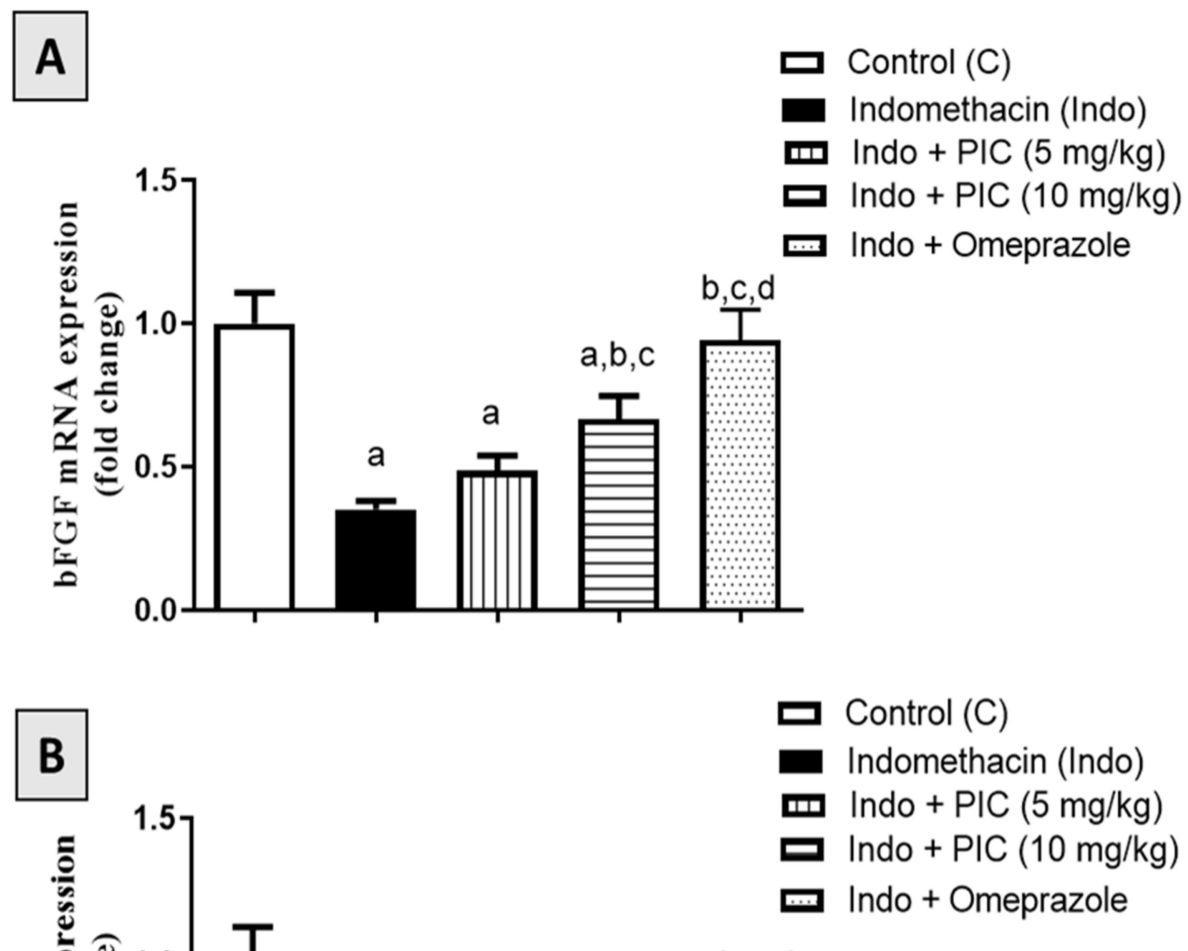

$a, b, c, d$

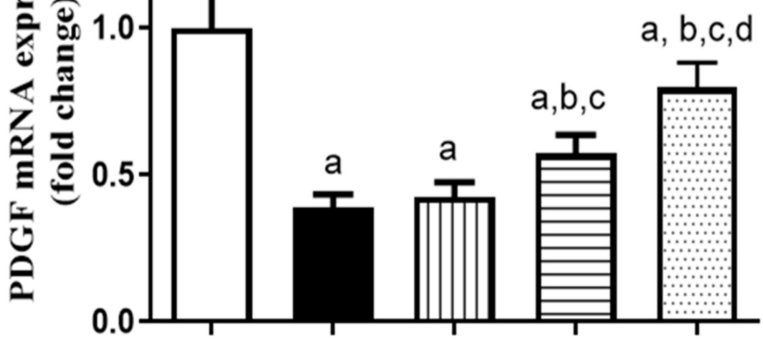

Figure 7. Effect of PIC pretreatment on (A) bFGF and (B) PDGF mRNA expression levels in gastric ulcer induced by Indo. Data are presented as Mean \pm SD $(n=6)$. a: Significantly disparate with control $(p<0.05)$. b: Significantly disparate with Indo $(p<0.05)$; : Significantly disparate with Indo + PIC $(5 \mathrm{mg} / \mathrm{kg})(p<0.05) ; \mathrm{d}$ : Significantly disparate with Indo + PIC $(10 \mathrm{mg} / \mathrm{kg})(p<0.05)$.

\section{Discussion}

One of the most common diseases suffered by people in their lifetime is a gastric ulcer, which is driven by several mucosal factors [26,27]. A study revealed several mechanisms of gastric mucosal defense systems, like mucus bicarbonate phospholipid barrier, epithelial cells derived mucus/bicarbonate production, mucosal cell renewal, etc., are involved. The study also revealed the mechanisms of gastric mucosal damage [28]. NSAIDs are associated with gastric ulcer development and other adverse effects on the gastrointestinal environment [29]. Additionally, a previous study showed that Indo causes gastric injury in rats by inducing the reactive oxygen species (ROS) level [30,31]. In contrast, PIC is a known natural polyphenolic stilbene [32] and a resveratrol metabolite that exerts potent antioxidant and cytoprotective roles, and ROS chelation $[33,34]$. A previous study showed that gastric injury induced by Indo in rats can be reversed by L-arginine and Chinese sumac $[35,36]$. PIC-mediated reversal of gastric injury induced by the Indo study has been overlooked. Hence, this study aimed to investigate this gap.

Our experimental results showed that the Indo group had a severe hemorrhagic ulcerative mucosal lesion, associated with intense expression of COX-2, IL6, TNF $\alpha, \mathrm{NF}-\mathrm{kB}$, and lower expression of VEGFA, compared to the control group. In addition, it also showed higher gastric juice volume with lower gastric $\mathrm{pH}$. The mucin level in the Indo-treated group was also reduced. This was also reported in a previous study [37]. Additionally, the PGE2 level and the expression of bFGF and PDGF were also reduced. Compared to 
the control, the Indo group also had an induced MDA level, reduced GSH content, and depleted SOD and CAT activity that denotes the upraise of ROS induction pathway. A similar previous study also supported these findings [38]. Cumulatively the Indo group results indicate a severe gastric injury and delayed healing. One previous rat study showed that Indo induced the COX-2 expression [39]; simultaneously, another previous study revealed that Indo has been shown to induce the IL6/TNF $\alpha$ level and inhibited the PGE2 level [40]. While in normal gastric mucosa COX-1 is the predominant COX isoenzyme, there is increasing evidence that detectable amounts of COX-2 mRNA and protein are expressed both constitutively and inducible in gastric mucosa [41]. Several reports indicated an increased expression of COX-2 in damaged gastric mucosa [42-44]. In particular, our data gain support by several studies reporting an association between Indo-induced gastric injury and enhanced expression of COX-2 [6,39]. Up-regulation of COX-2 expression following inhibition of COX-1 may represent a compensatory response to inhibition of PG biosynthesis and contribute to the maintenance of the mucosal integrity under such conditions. This has been explained on the basis that gastric hypermotility is critical for the occurrence of initial damage under PG deficiency caused by NSAIDs [45,46]. Controversial findings regarding PDGF and FGF2 in Indo-treated rats were also reported [47,48].

In contrast, Indo+ PIC (5 mg/ kg) showed superficial injuries with focal necrosis, associated with moderate expression of COX-2, IL6, TNF $\alpha$, NF-kB, and VEGFA compared to the Indo group. The mucin level in this group showed a significant increase compared to the Indo group. Similar results were also found in the case of the PGE2 level. Compared to the Indo group, it also had a significant reduction in MDA level and slight induction of GSH content, and an increase in the SOD and CAT activity. It also significantly increases the bFGF and promotes cellular growth. Interestingly, pretreatment of PIC $(5 \mathrm{mg} / \mathrm{kg}) \mathrm{did}$ not significantly affect PDGF mRNA expression.

These results have been observed in the case of rats treated with Indo + PIC (10 mg/kg). It showed that treatment reversed the gastric injuries induced by Indo and exhibit normal mucosa. Additionally, it had lower expression of COX-2, IL-6, TNF- $\alpha$, and NFkB, and was associated with a significant reduction in gastric volumes and induced level of gastric $\mathrm{pH}$. Surprisingly it did not induce the mucin level compared to Indo + PIC (5 mg/ kg); however, it slightly induced the PGE2 level. Furthermore, induction of bFGF and PDGF mRNA were observed in the PIC $(10 \mathrm{mg} / \mathrm{kg})$ pretreated group. It also showed a significant reduction in MDA, induction of GSH, and enhancement of SOD and CAT activity. The previous studies also revealed that PIC has a therapeutic role especially in metabolic disorders like antioxidant (through lowering ROS), anti-inflammatory (through lowering IL-6, TNF- $\alpha$ ), and by suppressing the cytokine signaling pathways [16,32]. Another study showed that PIC reduced 12-O-tetradecanoylphorbol-13-acetate (TPA) induced COX-2 expression by blocking the activity of NF-kB [19]. However, no direct study regarding the effect of PIC on gastric ulcers has been found yet.

The most effective results have been observed in the Indo + omeprazole group. It showed the damage of stomach mucosa was normalized by obtaining intense expression of COX-2 and VEGFA, and weak expression of other cytokines (IL-6, TNF- $\alpha$ ). Additionally, the omeprazole pretreated group had a significantly lower level of gastric volumes and a significantly increased amount of gastric $\mathrm{pH}$ compared to other groups. Interestingly, omeprazole induces mucin content slightly more compared to other groups with a slight reduction in PGE-2 content compared to Indo + PIC (10 mg/kg). Moreover, it had a significant induction of bFGF in line with previous findings [38]. Omeprazole also increased the PDGF mRNA expression. The antioxidant results of the omeprazole pretreated group suggested a reduction in the level of ROS from the significant reduction in MDA level and significant induction of GSH content and SOD activity. Surprisingly, it slightly reduced CAT activity compared to Indo + PIC $(10 \mathrm{mg} / \mathrm{kg})$. A previous study showed that omeprazole assists in ulcer healing by inducing COX-2 and PGE2 levels. The authors of this study suggested that the gastrin-dependent pathway is accountable for increased expression of COX-2 and elevated levels of PGE2 [49,50]. In other words, NF-kB-dependent induction of 
COX-2 has minor or no effect on the anti-ulcerogenic activity of omeprazole. This is because NSAID-induced gastric damage is known to include acid-dependent lesions, and because omeprazole inhibits gastric acid secretion through suppression of $\mathrm{H}+/ \mathrm{K}+$ ATPase in the parietal cells [51]. Moreover, a previous study also showed an omeprazole-like proton pump inhibitor (PPI) [52] induced the VEGFA expression [53]. Similar findings regarding MDA, GSH, SOD, and CAT levels were also found in previous rat studies [54].

\section{Conclusions}

From the above discussion, it may be concluded that treatment with PIC may normalize the gastric injuries induced by Indo. This finding could lead to strategies for treating gastric ulcers by a surplus of new therapy over conventional treatment.

Author Contributions: Conceptualization, R.A.S. and B.G.E.; methodology, R.A.S. and B.G.E.; software, R.A.S. and B.G.E.; validation, R.A.S. and B.G.E.; formal analysis, R.A.S. and B.G.E.; investigation, R.A.S. and B.G.E.; resources, R.A.S. and B.G.E.; data curation, R.A.S. and B.G.E.; writing-original draft preparation, R.A.S. and B.G.E.; writing-review and editing, R.A.S. and B.G.E.; visualization, R.A.S. and B.G.E.; supervision, R.A.S. and B.G.E.; project administration, R.A.S. and B.G.E.; funding acquisition, R.A.S. All authors have read and agreed to the published version of the manuscript.

Funding: This project was funded by the Deanship of Scientific Research (DSR) at King Abdulaziz University, Jeddah, under grant no. (G: 372-166-1442). The authors, therefore, acknowledge with thanks to DSR for technical and financial support.

Institutional Review Board Statement: The study was conducted according to the guidelines of the Declaration of Helsinki, and approved by the Research Ethics Committee, Faculty of Pharmacy, King Abdulaziz University (Approval Reference \# PH133-41).

Informed Consent Statement: Not applicable.

Data Availability Statement: Data are contained within the article.

Acknowledgments: This project was funded by the Deanship of Scientific Research (DSR) at King Abdulaziz University, Jeddah, under grant no. (G:372-166-1442). The authors, therefore, acknowledge, with thanks, DSR for technical and financial support. Also, the authors are grateful to Gamal S. Abd El-Aziz, Department of Anatomy, Faculty of Medicine, King Abdulaziz University for his help in the histopathological examinations.

Conflicts of Interest: The authors declare no conflict of interest.

\section{References}

1. Boligon, A.A.; De Freitas, R.B.; De Brum, T.F.; Waczuk, E.P.; Klimaczewski, C.V.; De Ávila, D.S.; Athayde, M.L.; De Bauermann, L.F. Antiulcerogenic activity of Scutia buxifolia on gastric ulcers induced by ethanol in rats. Acta Pharm. Sin. B 2014, 4, 358. [CrossRef]

2. Abbas, A.M.; Sakr, H.F. Effect of selenium and grape seed extract on indomethacin-induced gastric ulcers in rats. J. Physiol. Biochem. 2013, 69, 527-537. [CrossRef]

3. Brooks, P.; Emery, P.; Evans, J.F.; Fenner, H.; Hawkey, C.J.; Patrono, C.; Smolen, J.; Breedveld, F.; Day, R.; Dougados, M.; et al. Interpreting the clinical significance of the differential inhibition of cyclooxygenase-1 and cyclooxygenase-2. Rheumatology 1999, 38, 779-788. [CrossRef]

4. Hamdan, D.I.; El-Shiekh, R.A.; El-Sayed, M.A.; Khalil, H.M.A.; Mousa, M.R.; Al-Gendy, A.A.; El-Shazly, A.M. Phytochemical characterization and anti-inflammatory potential of Egyptian Murcott mandarin cultivar waste (stem, leaves and peel). Food Funct. 2020, 11, 8214-8236. [CrossRef]

5. Musumba, C.; Pritchard, D.M.; Pirmohamed, M. Review article: Cellular and molecular mechanisms of NSAID-induced peptic ulcers. Aliment. Pharmacol. Ther. 2009, 30, 517-531. [CrossRef]

6. Suleyman, H.; Albayrak, A.; Bilici, M.; Cadirci, E.; Halici, Z. Different mechanisms in formation and prevention of indomethacininduced gastric ulcers. Inflammation 2010, 33, 224-234. [CrossRef]

7. Yadav, S.K.; Adhikary, B.; Chand, S.; Maity, B.; Bandyopadhyay, S.K.; Chattopadhyay, S. Molecular mechanism of indomethacininduced gastropathy. Free Radic. Biol. Med. 2012, 52, 1175-1187. [CrossRef]

8. Utsumi, H.; Yasukawa, K.; Soeda, T.; Yamada, K.I.; Shigemi, R.; Yao, T.; Tsuneyoshi, M. Noninvasive mapping of reactive oxygen species by in vivo electron spin resonance spectroscopy in indomethacin-induced gastric ulcers in rats. J. Pharmacol. Exp. Ther. 2006, 317, 228-235. [CrossRef] [PubMed] 
9. Tarnawski, A.S. Cellular and molecular mechanisms of gastrointestinal ulcer healing. Dig. Dis. Sci. 2005, 50 (Suppl. 1), S24-S33. [CrossRef] [PubMed]

10. Milani, S.; Calabrò, A. Role of growth factors and their receptors in gastric ulcer healing. Microsc. Res. Tech. 2001, 53, 360-371. [CrossRef] [PubMed]

11. Chen, W.P.; Hung, L.M.; Hsueh, C.H.; Lai, L.P.; Su, M.J. Piceatannol, a derivative of resveratrol, moderately slows INa inactivation and exerts antiarrhythmic action in ischemia-reperfused rat hearts. Br. J. Pharmacol. 2009, 157, 381. [CrossRef]

12. Akinwumi, B.C.; Bordun, K.A.M.; Anderson, H.D. Biological Activities of Stilbenoids. Int. J. Mol. Sci. 2018, 19, 792. [CrossRef]

13. Surh, Y.J.; Na, H.K. Therapeutic Potential and Molecular Targets of Piceatannol in Chronic Diseases. Adv. Exp. Med. Biol. 2016, 928, 185-211. [CrossRef]

14. Tang, Y.L.; Chan, S.W. A review of the pharmacological effects of piceatannol on cardiovascular diseases. Phytother. Res. 2014, 28, 1581-1588. [CrossRef]

15. Kiliç, V. Piceatannol Mediated Modulation of Oxidative Stress and Regeneration in the Liver of Endotoxemic Mice. J. Med. Food 2019, 22, 594-601. [CrossRef]

16. Cao, Y.; Smith, W.; Yan, L.; Kong, L. Overview of Cellular Mechanisms and Signaling Pathways of Piceatannol. Curr. Stem. Cell Res. Ther. 2020, 15, 4-10. [CrossRef]

17. Jeong, S.O.; Son, Y.; Lee, J.H.; Cheong, Y.K.; Park, S.H.; Chung, H.T.; Pae, H.O. Resveratrol analog piceatannol restores the palmitic acid-induced impairment of insulin signaling and production of endothelial nitric oxide via activation of anti-inflammatory and antioxidative heme oxygenase-1 in human endothelial cells. Mol. Med. Rep. 2015, 12, 937-944. [CrossRef]

18. Jin, C.Y.; Moon, D.O.; Lee, K.J.; Kim, M.O.; Lee, J.D.; Choi, Y.H.; Park, Y.M.; Kim, G.Y. Piceatannol attenuates lipopolysaccharideinduced NF-kappaB activation and NF-kappaB-related proinflammatory mediators in BV2 microglia. Pharmacol. Res. 2006, 54, 461-467. [CrossRef]

19. Liu, L.; Li, J.; Kundu, J.K.; Surh, Y.J. Piceatannol inhibits phorbol ester-induced expression of COX-2 and iNOS in HR-1 hairless mouse skin by blocking the activation of NF-kB and AP-1. Inflamm. Res. 2014, 63, 1013-1021. [CrossRef]

20. Wahdan, S.A.; Azab, S.S.; Elsherbiny, D.A.; El-Demerdash, E. Piceatannol protects against cisplatin nephrotoxicity via activation of Nrf2/HO-1 pathway and hindering NF-kB inflammatory cascade. Naunyn. Schmiedebergs Arch. Pharmacol. 2019, 392, 1331-1345. [CrossRef]

21. Sathish, R.; Vyawahare, B.; Natarajan, K. Antiulcerogenic activity of Lantana camara leaves on gastric and duodenal ulcers in experimental rats. J. Ethnopharmacol. 2011, 134, 195-197. [CrossRef] [PubMed]

22. Suvarna, K.S.; Layton, C.; Bancroft, J.D. (Eds.) Bancroft's Theory and Practice of Histological Techniques E-Book; Elsevier Health Sciences: Amsterdam, The Netherlands, 2018.

23. AlKreathy, H.M.; Alghamdi, M.K.; Esmat, A. Tetramethylpyrazine ameliorates indomethacin-induced gastric ulcer in rats: Impact on oxidative, inflammatory, and angiogenic machineries. Saudi Pharm. J. SPJ Off. Publ. Saudi Pharm. Soc. 2020, $28,916-926$. [CrossRef] [PubMed]

24. Kei, S. Serum lipid peroxide in cerebrovascular disorders determined by a new colorimetric method. Clin. Chim. Acta 1978, 90, 37-43. [CrossRef]

25. Nishikimi, M.; Appaji Rao, N.; Yagi, K. The occurrence of superoxide anion in the reaction of reduced phenazine methosulfate and molecular oxygen. Biochem. Biophys. Res. Commun. 1972, 46, 849-854. [CrossRef]

26. Laine, L.; Takeuchi, K.; Tarnawski, A. Gastric Mucosal Defense and Cytoprotection: Bench to Bedside. Gastroenterology 2008, 135, 41-60. [CrossRef]

27. Shaker, E.; Mahmoud, H.; Mnaa, S. Anti-inflammatory and anti-ulcer activity of the extract from Alhagi maurorum (camelthorn) Food Chem. Toxicol. 2010, 48, 2785-2790. [CrossRef]

28. Fornai, M.; Antonioli, L.; Colucci, R.; Tuccori, M.; Blandizzi, C. Pathophysiology of Gastric Ulcer Development and Healing: Molecular Mechanisms and Novel Therapeutic Options. Peptic Ulcer Dis. 2011, 113-142. [CrossRef]

29. Russell, R.I. Non-steroidal anti-inflammatory drugs and gastrointestinal damage-Problems and solutions. Postgrad. Med. J. 2001, 77, 82-88. [CrossRef]

30. Maity, P.; Bindu, S.; Dey, S.; Goyal, M.; Alam, A.; Pal, C.; Mitra, K.; Bandyopadhyay, U. Indomethacin, a non-steroidal antiinflammatory drug, develops gastropathy by inducing reactive oxygen species-mediated mitochondrial pathology and associated apoptosis in gastric mucosa: A novel role of mitochondrial aconitase oxidation. J. Biol. Chem. 2009, 284, 3058-3068. [CrossRef]

31. Tastekin, E.; Ayvaz, S.; Usta, U.; Aydogdu, N.; Cancilar, E.; Oz Puyan, F. Indomethacin-induced gastric damage in rats and the protective effect of donkey milk. Arch. Med. Sci. 2018, 14, 671. [CrossRef]

32. Kershaw, J.; Kim, K.H. The Therapeutic Potential of Piceatannol, a Natural Stilbene, in Metabolic Diseases: A Review. J. Med. Food 2017, 20, 427. [CrossRef]

33. Da Costa, F.P.; Puty, B.; Nogueira, L.S.; Mitre, G.P.; Dos Santos, S.M.; Teixeira, B.J.B.; Kataoka, M.S.D.S.; Martins, M.D.; Barboza, C.A.G.; Monteiro, M.C.; et al. Piceatannol Increases Antioxidant Defense and Reduces Cell Death in Human Periodontal Ligament Fibroblast under Oxidative Stress. Antioxidants 2020, 9, 16. [CrossRef]

34. Piotrowska, H.; Kucinska, M.; Murias, M. Biological activity of piceatannol: Leaving the shadow of resveratrol. Mutat. Res. 2012, 750, 60-82. [CrossRef]

35. Guha, P.; Dey, A.; Chatterjee, A.; Chattopadhyay, S.; Bandyopadhyay, S.K. Pro-ulcer effects of resveratrol in mice with indomethacin-induced gastric ulcers are reversed by L-arginine. Br. J. Pharmacol. 2010, 159, 726-734. [CrossRef] 
36. Ma, N.; Sun, Y.; Yi, J.; Zhou, L.; Cai, S. Chinese sumac (Rhus chinensis Mill.) fruits alleviate indomethacin-induced gastric ulcer in mice by improving oxidative stress, inflammation and apoptosis. J. Ethnopharmacol. 2022, 284, 114752. [CrossRef] [PubMed]

37. Sabiu, S.; Garuba, T.; Sunmonu, T.; Ajani, E.; Sulyman, A.; Nurain, I.; Balogun, A. Indomethacin-induced gastric ulceration in rats: Protective roles of Spondias mombin and Ficus exasperata. Toxicol. Rep. 2015, 2, 261. [CrossRef]

38. Olaleye, S.B.; Farombi, E.O. Attenuation of indomethacin- and $\mathrm{HCl}$ /ethanol-induced oxidative gastric mucosa damage in rats by kolaviron, a natural biflavonoid of Garcinia kola seed. Phytother. Res. 2006, 20, 14-20. [CrossRef]

39. Takeuchi, K.; Tanaka, A.; Hayashi, Y.; Kubo, Y. Functional mechanism underlying COX-2 expression following administration of indomethacin in rat stomachs: Importance of gastric hypermotility. Dig. Dis. Sci. 2004, 49, 180-187. [CrossRef]

40. Gentile, L.B.; Queiroz-Hazarbassanov, N.; Massoco, C.D.O.; Fecchio, D. Modulation of cytokines production by indomethacin acute dose during the evolution of Ehrlich Ascites tumor in mice. Mediat. Inflamm. 2015, 2015, 1-8, 924028. [CrossRef]

41. Halter, F.; Tarnawski, A.S.; Schmassmann, A.; Peskar, B.M. Cyclooxygenase 2-implications on maintenance of gastric mucosal integrity and ulcer healing: Controversial issues and perspectives. Gut 2001, 49, 443-453. [CrossRef]

42. Mizuno, H.; Sakamoto, C.; Matsuda, K.; Wada, K.; Uchida, T.; Noguchi, H.; Akamatsu, T.; Kasuga, M. Induction of cyclooxygenase 2 in gastric mucosal lesions and its inhibition by the specific antagonist delays healing in mice. Gastroenterology 1997, 112, 387-397. [CrossRef] [PubMed]

43. Davies, N.M.; Sharkey, K.A.; Asfaha, S.; Macnaughton, W.K.; Wallace, J.L. Aspirin causes rapid up-regulation of cyclo-oxygenase-2 expression in the stomach of rats. Aliment. Pharmacol. Ther. 1997, 11, 1101-1108. [CrossRef]

44. Kishimoto, Y.; Wada, K.; Nakamoto, K.; Kawasaki, H.; Hasegawa, J. Levels of cyclooxygenase-1 and -2 mRNA expression at various stages of acute gastric injury induced by ischemia-reperfusion in rats. Arch. Biochem. Biophys. 1998, 352, 153-157. [CrossRef]

45. Takeuchi, K.; Ueshima, K.; Hironaka, Y.; Fujioka, Y.; Matsumoto, J.; Okabe, S. Oxygen free radicals and lipid peroxidation in the pathogenesis of gastric mucosal lesions induced by indomethacin in rats. Relation to gastric hypermotility. Digestion 1991, 49, 175-184. [CrossRef] [PubMed]

46. Okada, M.; Niida, H.; Takeuchi, K.; Okabe, S. Role of prostaglandin deficiency in pathogenetic mechanism of gastric lesions induced by indomethacin in rats. Dig. Dis. Sci. 1989, 34, 694-702. [CrossRef] [PubMed]

47. Lonnroth, C.; Svaninger, G.; Gelin, J.; Cahlin, C.; Iresjo, B.M.; Cvetkovska, E.; Edstrom, S.; Andersson, M.; Svanberg, E.; Lundholm, $\mathrm{K}$. Effects related to indomethacin prolonged survival and decreased tumor-growth in a mouse-tumor model with cytokine dependent cancer cachexia. Int. J. Oncol. 1995, 7, 1405-1413. [CrossRef] [PubMed]

48. Mucha, K.; Foroncewicz, B.; Koziak, K.; Czarkowska-Paczek, B.; Paczek, L. The effects of indomethacin on angiogenic factors mRNA expression in renal cortex of healthy rats. J. Physiol. Pharmacol. Off. J. Pol. Physiol. Soc. 2007, 58, 165-178.

49. Poonam, D.; Vinay, C.S.; Gautam, P. Cyclo-oxygenase-2 expression and prostaglandin E2 production in experimental chronic gastric ulcer healing. Eur. J. Pharmacol. 2005, 519, 277-284. [CrossRef]

50. Okabe, S.; Miyake, H.; Awane, Y. Cytoprotective effects of NC-1300 and omeprazole on Hcl. ethanol-induced gastric lesions in rats. Jpn. J. Pharmacol. 1986, 42, 123-133. [CrossRef]

51. Yamamoto, O.; Okada, Y.; Okabe, S. Effects of a proton pump inhibitor, omeprazole, on gastric secretion and gastric and duodenal ulcers or erosions in rats. Dig. Dis. Sci. 1984, 29, 394-401. [CrossRef]

52. Robinson, M.; Horn, J. Clinical pharmacology of proton pump inhibitors: What the practising physician needs to know. Drugs 2003, 63, 2739-2754. [CrossRef] [PubMed]

53. Yagi, K.; Mitstui, M.; Zamami, Y.; Niimura, T.; Izawa-Ishizawa, Y.; Goda, M.; Chuma, M.; Fukunaga, K.; Shibata, T.; Ishida, S.; et al. Investigation of drugs affecting hypertension in bevacizumab-treated patients and examination of the impact on the therapeutic effect. Cancer Med. 2021, 10, 164. [CrossRef] [PubMed]

54. Swamy, A.H.M.V.; Sajjan, M.; Thippeswamy, A.H.M.; Koti, B.C.; Sadiq, A.J. Influence of Proton Pump Inhibitors on Dexamethasone-Induced Gastric Mucosal Damage in Rats. Indian J. Pharm. Sci. 2011, 73, 193. [CrossRef] [PubMed] 